\title{
CURRENT CONDITION IN PIG PRODUCTION AND POTENTIALS FOR DEVELOPMENT $^{1}$
}

\author{
Milica Petrović, D. Radojković, M. Mijatović ${ }^{2}$
}

Contents: In this paper, the situation in pig production of the Republic of Serbia is presented and analyzed, starting from the number of heads of pigs, production of meat, breed structure to production parameters on farms. Certain measures are recommended for improvement of the pig production.

Key words: pig production, number of heads of pigs, production of meat, production indicators, development measures

\section{Introduction}

Pig production is very important branch of livestock production. Main product deriving from this modern and organized production is meat - pork. It is at the same time raw material for further processing. Apart from several very important traits of pigs, one which makes them different from all other domestic animals is considerable quantity of meat that can be produced per sow annually $(1800-2000 \mathrm{~kg}$ live weight of fatteners or $1440-1600 \mathrm{~kg}$ of carcass sides or $720-800 \mathrm{~kg}$ of meat). Countries with developed pig production, among other things, try to increase the production of high quality pork. Objective is not only to produce pigs with high quality carcass but also to produce carcass with high quality meat.

Data on production of meat in the World and Europe confirms the importance of this production - in total meat production pork participates with 40 to $50 \%$. There are certain variations in production of pork among EU countries, but in some European countries production of pork participated with 60 to $80 \%$ in total production of meat.

\section{Current condition in pig production and breed structure}

\section{Number of heads of pigs}

Total number of heads of pigs changed from year to year. In following periods 1965-1974, 1975 1984, 1985-1994 and 1995-2004 in the Republic of Serbia in average: 3666 600; 4796 000; 4437900 and 3 954800 pigs were reared, respectively $(S G S, 2004)$. Average number of sows and pregnant gilts in mentioned periods was o: 698 900; 885 800; 863700 and 838000 heads, respectively. Average number of pigs and sows and pregnant gilts in period 1965-2004 was 4.213 million and 821.6 thousands of heads, respectively. Relative varying of the total number of pigs was highest in the period from 1965-1974 and 1985-1994. The highest number of pigs since 1965 until today was in year 1984 (5.561 million heads, of which 1.002 million were sows and pregnant gilts). In that year there were 59.8 pigs per 100 inhabitants.

In investigated period, number of pigs per 100 inhabitants varied in different years from 41.6 to 47.8 heads. Also the distribution and level of development of pig production varied. The majority of pigs are reared in region of Mačva followed by South Banat district. However, districts of Mačva and Danube had the highest number of pigs per 100 ha of crop plough fields/surface.

Tešić et al. (2002) have established high variability and cyclic nature in number of heads of pigs. By investigating the period from year 1976 to 2000 they have determined annual decrease of 31374 heads of total number of pigs and 706 sows and pregnant gilts in Serbia. Until 1990, cycles when number of heads of pigs varied lasted longer (4 to 6 years) with different durations of expansion and contraction phases. After 1990 , cycles were shorter ( 2 to 4 years) with more equal phases and authors concluded that this was consequence of disrupted economical relations in the country. In the same period production of pig meat showed increase rate of $1.4 \%$.

1 Review paper invited - Uvodni rad po pozivu

2 Dr Milica Petrović, full professor; mr Dragan Radojković, asisstant; mr Milan Mijatović, asisstant, Faculty of Agriculture, BelgradeZemun 
Since year 1999 there are no data for Kosovo and Metohija. Total number of heads of pigs decreased until 2002 (from 4.293 to 3.587 million heads), in 2003 it increased (3 634000 ) only to decrease again in 2004 (3 439 000). Number of sows and pregnant gilts in the same period decreased over the period of first three years (from 896 to 790000 ), subsequently it increased in next two years (to 825000 ) but considerably decreased in the last year (692 000 heads). If we compare 2003 and 2004 it can be observed that in total decrease of number of heads of pigs (- 195000 heads) main decrease occurred in main herd - female breeding heads (- 133000 heads or $68.2 \%$ of total decrease).

Agricultural firms and enterprises reared in average 751645 pigs and 87394 sows and pregnant gilts, which is 20.1 and $10.6 \%$ respectively of average number of heads of pigs in Serbia in period 1990-2003 (SG SCG,2004). This means that pigs are mainly reared on individual farms (approx. $80 \%$ of pigs and $89 \%$ sows and pregnant gilts).

According to Census - Registration of inhabitants, households and apartments (SZS-RZSS, 2002) in Republic of Serbia there were 778891 of agricultural households where 2164726 heads of pigs were reared. Agricultural households had in average 2.8 pigs. Average number of pigs per agricultural household was higher in Vojvodina (3.5 pigs) than in Central Serbia (2.5 pigs). Average number of pigs per hectare of cultivable land used by agricultural households was 1.1. Number of pigs on agricultural household varied in different districts - from 0.96 (Pirot district) to 10.04\% (Mačva district) of total number of pigs in Republic of Serbia.

\section{Breed structure}

On farms in Serbia mainly meat/fattening pig breeds and crosses are reared. In our pig herds the following breeds are reared: Landraces (Swedish, Dutch, German, Belgian, and Danish), Large Yorkshire, Domestic meat pig, Hampshire, Durroc and Pietrain. The majority of pigs are Swedish Landrace and Large Yorkshire. Share of meat/fattening breeds used as terminal breeds in crossing is low with tendency of increase of share of Durroc and decrease of share of Hampshire breed. Recently, import of heads of Pietrain, German landrace and hybrid pigs has increased, with usual import of fertile meat breeds. Beside pure breeds also crosses are produced and reared which make over $60 \%$ of total number of sows included in control. Private pig producers also rear some of the meat breeds and crosses.

Of native - autochthonous breeds there are still Mangulica, Moravka and Resavka in rearing which are included in the programme of preservation of animal genetic resources.

\section{Production of pig meat - pork}

Annual production of pig meat in period 1990-2003 in average was 268800 and varied in different years from 243000 to 292000 tons. In period from 1999 to 2003, production of pig meat decreased (19992001), in 2002 it increased and decreased again in 2003. Over the period of last five years over $55 \%$ of total produced quantities of meat in Republic of Serbia was pork. Over $60 \%$ of pig meat was produced in Central Serbia and less than $40 \%$ in Vojvodina. However, share of pork in total amount of produced meat was higher in Vojvodina (average of $60.5 \%$ ) than in Central Serbia (average of $54.1 \%$ ).

Of total number of slaughtered heads of pigs, piglets (approx. 38\%) and meat/fattening pigs (approx 33 to $37 \%$ ) are slaughtered the most. Share of slaughtered fatty pigs is relatively high ( 24 to $29 \%$ ). However, the ratio of slaughtered meat/fattening and fatty pigs is changing in favour of meat pigs. In year 1999 this ratio was 1.21:1 and in 2003 1.54:1. Average gross mass of slaughtered piglets, meaty and fatty pigs in slaughterhouses was approx. 21, 100 and $168 \mathrm{~kg}$, respectively. It is estimated that in year 2010 production of pig meat in Serbia and Montenegro will be $400000 \mathrm{t}$ (Baltic et al.,2002).

There are several reasons leading to displayed negative trend in pig production and production of pig meat in our country. On the other hand, production of pig meat in the world is constantly increasing. It increased from 67 (1991) to 90 million tons (1999). Estimations of FAO for year 2005 are that production of pig meat will increase $2.6 \%$ and will amount to 103.4 million tons. Production of pig meat in the world was 98.5 million tons in 2003 and 100.8 million tons in 2004 (Pig International-eNews, 2005). By the end of 2004 (Eurostat) in EU-25 there were 151657000 pigs, 15230000 or $10.04 \%$ of total number were breeding heads. Majority of pigs were reared in Germany, Spain, Poland, France, Denmark and The Netherlands (from 11.1 to 26.3 million heads). In 2004, countries of EU produced $21267000 \mathrm{t}$ of pig meat. It is expected that production of pig meat in 2005 reach 21.5 million tons and in 2010/2011 from 22.25 to 22.5 million tons. 
Average consumption of pig meat in Serbia in 2003 was $15.7 \mathrm{~kg}$ and in $200415.9 \mathrm{~kg} / \mathrm{capita}$. It is expected in 2005 that the consumption of this type of meat increases to $16.3 \mathrm{~kg}$. In EU countries, consumption of pig meat per capita is approx. $45 \mathrm{~kg}$ and in 2010 it is expected to increase to $48 \mathrm{~kg}$ (Pig InternationaleNews, 2005). In year 2004, in countries of EU, of total amount of consumed meat per capita share of pig meat was higher than $50 \%$ which indicates also the significance of this production. Competition advantage of pig production on the market compared to other types of meat is result of high productivity which affects the cost of production and price of $\mathrm{kg}$ of live weight.

Average consumption of pig meat per capita in Serbia in period from 1990 to 2000 (Tešić et al., 2002) was $27.77 \mathrm{~kg}$ with decreasing tendency of $2,3 \%$. Authors have established that income and high prices were main limiting factor in consumption of pig meat. Self-sufficiency in pig meat was higher than 100 index points, in other words our country experienced suficit in this product. It is considered that suficit is result of low consumption of pig meat and not of high production.

\section{Production parameters on pig farms in Serbia}

Since last decade of the twentieth century until today conditions in pig production have worsened considerably. Reasons of such unfavourable trend in pig production and production of pig meat are versatile, different and specific for certain periods, for instance during the nineties and after year 2000. Unsolved issue regarding ownership, different success in privatization, lack of adaptability to new conditions of the economy, slow process of transition and general changes, lost markets, unfavourable parities of prices, etc. have caused reduction of production volume and quality of product.

Over the ten year period (1991-2000), on farms in Central Serbia, sows included in the control programme have farrowed in average 10.03 piglets per litter in which 9.44 were live born piglets (Petrović et al.,2002). In year 2000 all values of fertility traits were lower than in 1991. Reproductive traits of sows varied from year to year. Variation interval for same trait was higher between farms than years of control Production results obtained on farms in Central Serbia and Vojvodina in 2000 clearly indicated problems in this production. Very few farms realized good results. In Vojvodina, only on 32\% (Gagrčin et al., 2001) and in Central Serbia on $28 \%$ of farms percentage of farrowed sows was higher than 75 . Ten and more live born piglets were farrowed by sows on approx. 175 of farms in Vojvodina and on 10\% of farms in Central Serbia. Losses of piglets were high, especially on some farms. Fatteners realized daily gain over $600 \mathrm{~g}$ on $21 \%$ of farms in Vojvodina and on $27 \%$ of farms in Central Serbia. Number of fatteners per sow annually was low. Of total number of farms included in control programme in Vojvodina and Central Serbia, 25 and 14\% respectively achieved 15 fatteners per sow annually. During 2003 and 2004 fertility of pigs on farms under control in Central Serbia increased, so in average sows farrowed 9.75 and 9.89 live born or total of 10.33 and 10.37 piglets. Sows reared in average per weaned litter 8.28 and 8.86 piglets.

On farms in Central Serbia, since 1991, number of tested boars and gilts decreased. Average daily gain of performance tested gilts was higher in 2003 (511g) than in period 1991-2000 (458 g). However, average daily gain of boars was lower in $2003(775 \mathrm{~g})$ than in period 1991-2000 (793 g). Content of meat in carcasses of gilts and boars measured using ultrasound equipment increased in 2003 (56.12 and 56.58\%) compared to period 1991-2000 (53.08 and 55.30\%).

Presented and achieved results are not satisfactory. Certain farmers in Central Serbia created crosses by unplanned crossing of breeds, so there are farmers rearing more than ten genotypes and those determined as „other crosses“. Few of the private family farms are included in programme of control/testing of pig productivity. Insufficient male heads were included in performance testing. On some farms it is individual and on other farms group testing. Also, number of tested gilts is also insufficient.

\section{Proposed measures for improvement of pig production in Republic of Serbia}

Programme of breeding-selection work should enable systematic improvement of fertility traits, growth rate, feed conversion, carcass quality (more muscle tissue in carcass), meat quality and resistance of pigs to diseases and stress.

Specialization of production on the level of country, region, within company (association) or large farms and application of modern testing, selection and crossing methods should lead to improvement of the genetic basis of pigs. Breeding programmes should also be dynamic, they should include scientific 
achievements and be flexible and change depending on the consumer demand. In time when accurate and fast information for successful decision making are essential it is necessary to introduce unique registration (identification) and recording system, testing, control of pig traits, evaluation of breeding value and ranking of heads of pigs.

Permanent, systematic and planed breeding-selection work is essential if we want to:

- Increase the genetic potential of existing meat breeds and pig crosses,

- Work on creation of new lines within pure breeds,

- Introduce the genotypes of meat breeds and pig crosses from public farms to family farms,

- Apply modern methods of pig testing,

- Apply modern linear methods which will enable more accurate and precise evaluation of breeding value which will have direct influence on the success of selection and genetic improvement of pigs. Beside selection index for evaluation of breeding value other more precise linear methods should be used (BLUP, AM, REML, software package -PEST). These methods will enable use of information on pig traits from all segments or herds (nucleus, multiplying and commercial), centres for AI (artificial insemination), slaughterhouses, etc.

- Specialize production of high quality breeding animals for restoring, increasing of herd and sale of fatteners according to principle of breeding pyramid.

In order to improve pig traits it is necessary to modernize production management through use of computers in different fields (genetics, selection, reproduction, nutrition, health protection, etc.), active participation of scientific, research and expert potentials, permanent education and training and monitoring of the economical efficiency of production.

Forming and functioning of centres for AI enables improvement of pig production on regional level and also national. Centres house and utilize boars which were selected based on results of testing, phenotype, biological or test on molecular level, quantity or quality of semen. In this way it is possible to realize economical profit. Nucleus herds sell high quality breeding animals, centres for AI large quantity of sperm and commercial herds provide high quality heads for fattening and production of quality pig meat, and therefore they should give money from each slaughtered fattener for selection-breeding work. Government also realizes profit since costs of production of fatteners are reduced, high quality meat for the market and high quality breeding animals are produced, people are employed, as experts or labour.

It is necessary to spread from centres for AI high quality breeding animals to private farms. Private farms should become carriers of organized modern pig production with animals under control of production traits, or they would purchase high quality breeding animals, produce piglets for fattening or engage only in fattening. This means that private family farms should be connected with producers of breeding animals, centres for AI and slaughter industry. Private family farms should rear 50 and than 100 sows and 1000 or more fatteners in future ten year period.

Very serious activity and effort relating to unique system of identification of domestic animals is ahead of us. It is important not only because of the improvement of pig production through unique monitoring, investigation of production traits and evaluation of breeding value, health protection to monitoring of product quality.

It is necessary to form breeders' associations which should be different from those existing today in the field of pig breeding. Such associations should provide future development and carrying out of breedingselection work.

Through application of modern methods of pig testing, more accurate evaluation of breeding value, selection with improved conditions of housing and nutrition (according to international convention on protection of animals and their biological and ethological needs), it is necessary to strive towards higher productivity of sows - 20 fatteners per sow annually or $2.000 \mathrm{~kg}$ of live weight with over $55 \%$ of high quality meat in carcass of fatteners (three breed or three line crosses and/or four breed and four line crosses). Average daily gain of pigs in fattening in future should be $700-800 \mathrm{~g}$ and feed conversion $3 \mathrm{~kg}$ of feed. All of the above mentioned factors could lead to increase of pig meat production in annual rate of 2 to $2,5 \%$.

Special attention must be directed to preservation of genetic resources - autochthonous pig breeds (Mangulica, Moravka and Resavka). Their importance is not only in preservation of genes but also in utilization for improvement of pig production and production of meat and meat products (organic livestock production). 


\section{Conclusion}

Based on presented review of current condition in pig production in the Republic of Serbia, there are several questions of considerable importance which need to be answered: What is the foundation of this branch of livestock production to withstand what is imminent on our way to EU? We face great efforts on all levels on this journey. Law on animal breeding/livestock production is of special importance since it has to regulate many issues such as development programmes and measures; acknowledgment of breeders' associations and organizations in livestock production; unique registration and recording; standards for pure breeds; testing, control and evaluation of breeding value, etc.

Harmonization of our legislative regulations to EU will probably also encounter many problems and mistakes. It is necessary to try to maintain characteristics and specific traits of this region and our livestock production in this process of legislation harmonization.

\section{AKTUELNO STANJE I MOGUĆNOSTI RAZVOJA SVINJARSTVA}

Milica Petrović, D. Radojković, M. Mijatović

Rezime

U radu je prikazano i analizirano stanje u svinjarstvu Republike Srbije, polazeći od brojnog stanja, proizvodnje mesa, rasnog sastava do proizvodnih pokazatelja na farmama. Predložene su mere za unapredjenje proizvodnje u svinjarstvu. Navedeni su ciljevi koje bi bilo neophodno postići u proizvodnji svinja i svinjskog mesa.

Ključne reči: svinjarstvo, brojno stanje, proizvodnja mesa, proizvodni pokazatelji, mere razvoja.

Literature

1. BALTIĆ M.Ž., DRAGIĆEVIĆ OLGICA, KARABASIL N. (2002): Trendovi u potrošnji mesa. 14. savetovanje veterinara Srbije. Zbornik referata i kratkih sadržaja, 123-131.

2. GAGRČIN M., KOVČIN S., STANČIĆ B. (2001): Zdravstveni i proizvodni rezultati u farmama svinja sa područja Vojvodine za 2000. godinu. Savremena poljoprivreda, 50, 3-4, 251-256.

3. PETROVIĆ MILICA, TEODOROVIĆ M., RADOJKOVIĆ D., RADOVIĆ I. (2002): Varijabilnost proizvodnih osobina svinja na farmama u Srbiji. Veterinarski glasnik, 56, 1-2, 89-96.

4. PIG INTERNATIONAL Electronic Newsletter,2005.

5. POPIS STANOVNIŠTVA, DOMAĆINSTAVA I STANOVA 2002. PRVI REZULTATI POPISA PO OPŠTINAMA I NASELJIMA REPUBLIKE SRBIJE. Savezni zavod za statistiku-republički zavod za statistiku Srbije. Beograd, 2002.

6. STATISTIČKI GODIŠNJAK SCG (2004). Savezni zavod za statistiku, Beograd, 2004.

7. STATISTIČKI GODIŠNJAK SRBIJE (2004). Republički zavod za statistiku. Beograd, 2004.

8. STRATEGIJA INDUSTRIJSKOG RAZVOJA SRBIJE DO 2010. GODINE: Razvoj agroindustrije Srbije do 2010. godine. Projekat MNTR Republike Srbije, Beograd, 2001.

9. TEODOROVIĆ M., ANTOV G., MILOŠEVIĆ N. (2002): Aktuelno stanje i mogućnosti razvoja stočarstva. Savremena poljoprivreda, 51, 3-4, 13-18.

10. TEODOROVIĆ M., PETROVIĆ MILICA, RADOVIĆ I. (2002): Ugovorena proizvodnja svinja za tržište. Agroekonomika, 30, 110-119.

11. TEŠIĆ M., AVAKUMOVIĆ DJ., STANKOV M., MIRILOVIĆ M. (2002): Stanje i perspektive razvoja svinjarstva u Srbiji. 14. savetovanje veterinara Srbije. Zbornik referata i kratkih sadržaja, 3-15. 